\title{
Tissue Eosinophilia and Eosinophil Degranulation in Riedel's Invasive Fibrous Thyroiditis*
}

\author{
A. E. HEUFELDER, J. R. GOELLNER, R. S. BAHN, G. J. GLEICH, AND I. D. HAY \\ Molecular Thyroid Research Unit, Medizinische Klinik, Klinikum Innenstadt, Ludwig-Maximilians- \\ Universität (A.E.H.), Munich, Germany; the Division of Endocrinology, Department of Internal \\ Medicine (R.S.B., I.D.H.), Department of Pathology (J.R.G.), and Department of Immunology (G.J.G.), \\ Mayo Clinic/Foundation, Rochester, Minnesota 55905
}

\begin{abstract}
The etiology of Riedel's invasive fibrous thyroiditis (IFT) has remained obscure. This rare disorder has been confused in the past with the more common fibrous variant of Hashimoto's disease. The typical histological features of IFT, in particular the presence of an invasive fibrosclerotic process in conjunction with a prominent chronic inflammatory infiltrate, suggest that the release of fibrogenic cytokines and other factors from these cellular infiltrates may play an important role in the pathogenesis of this condition. Our observations in routinely processed tissue sections obtained from patients with documented IFT of striking tissue eosinophilia led us to hypothesize that eosinophils and their products may play a role in the evolution of this disease. Immu-
\end{abstract}

nofluorescence staining with affinity-purified polyclonal rabbit antibody directed against human eosinophil granule major basic protein revealed marked tissue eosinophilia and abundant extracellular deposition of major basic protein in all specimens from 16 patients with IFT. By contrast, only occasional eosinophils and no extracellular major basic protein were detected in control thyroid tissues obtained from patients with multinodular goiter, Graves' disease, Hashimoto's disease, and normal thyroid tissue. The presence of marked eosinophil infiltration and extracellular major basic protein deposition in IFT and other associated fibrosclerotic conditions suggests a role for eosinophils and their products in propagating the fibrogenesis seen in IFT. ( $J$ Clin Endocrinol Metab 81: 977-984, 1996)
$S^{\mathrm{I}}$ NCE its recognition in 1896 (1) and its histopathological description (2), invasive fibrous thyroiditis (IFT; Riedel's struma), the rarest type of thyroiditis, has remained a mysterious entity of unknown etiology. Clinically, IFT is characterized by the gradual emergence of a firm solid anterior neck mass. Histological examination shows a chronic inflammatory fibrous process frequently arising in conjunction with a preexisting goiter. The invasive fibrosclerotic process typically continues well beyond the thyroid capsule, progressively invading and destroying the thyroid gland and neighboring neck tissues (3-5). Histological features characteristic of IFT include a dense, partially inflammatory fibrosclerotic process that may replace the entire thyroid gland. This process typically infiltrates and encompasses surrounding neck structures, such as muscles, blood vessels, nerves, and trachea $(2,5)$. The inflammatory infiltrate is a mixed population of mononuclear cells, consisting predominantly of activated $\mathrm{T}$ lymphocytes, macrophages, and aggregates of B lymphocytes $(2,5-8)$. Frequently, IFT is associated with manifestations of extracervical fibrosis, which may occur in locations such as the orbit, the mediastinum, the biliary tract, and the retroperitoneum $(3,4)$.

The detection of thyroid-specific autoantibodies in many patients with IFT $(3,6,9)$, the response of IFT to corticoste-

Received August 28, 1995. Revision received October 18, 1995. Accepted October 26, 1995.

Address all correspondence and requests for reprints to: Armin E. Heufelder, M.D., Molecular Thyroid Research Unit, Medizinische Klinik, Klinikum Innenstadt, Ludwig-Maximilians-Universität, Ziemssenstra $\beta \mathrm{e} 1$, 80336 Munich, Germany.

* This work was supported in part by grants to A.E.H. from Deutsche Forschungsgemeinschaft (Bonn, Germany; He 1485/2-1 and He 1485/ 3-1) and grants from the NIH (AI-15231 and AI-09728). roids, and the presence of a mononuclear cell infiltrate within the fibrosclerotic process suggest an active immunemediated process in the pathogenesis of IFT. Paracrine and autocrine factors, released locally by infiltrating lymphocytes/macrophages and residential cells, may act as stimulators of the fibrogenic process $(10,11)$. However, a variety of products derived from other immunocompetent cells, such as mast cells and eosinophils, may also act as potent stimulators of fibrogenesis (12-15).

In the process of reviewing our institution's histological experience in 33 patients with IFT over the past $60 \mathrm{yr}$, we observed a striking degree of tissue eosinophilia in the majority of hematoxylin- and eosin-stained slides examined. Certain eosinophil products exert cytotoxic effects on mammalian cells and are known to activate basophils, platelets, and mast cells as well as to stimulate fibrogenic cellular functions (12-19). Major basic protein (MBP), one of several eosinophil products, has been localized to the eosinophil granule core $(12,20)$. The detection of its presence and release, both in vitro and in vivo, has been used as a marker of eosinophil infiltration and degranulation (20-22). Using an indirect immunofluorescence technique for localization of eosinophil granule MBP, we tested the hypothesis that tissue eosinophilia and eosinophil degranulation are present in biopsy specimens from patients with IFT. Our results indicate that eosinophil infiltration and degranulation are frequent and prominent features of the inflammatory fibrosis in IFT.

\section{Patients}

\section{Subjects and Methods}

Surgical biopsy specimens from 16 patients with histologically documented Riedel's invasive fibrous thyroiditis, diagnosed at the Mayo Clinic between 1932 and 1990, were evaluated. These tissue samples 
originated from 10 women and 6 men with a mean age of $51 \mathrm{yr}$ and a mean duration of disease of $2.8 \mathrm{yr}$ at the time of diagnosis. Control tissues included biopsy specimens of thyroid tissue obtained from normal individuals ( $\mathrm{n}=5$; autopsy specimens), patients with multinodular goiter $(n=4)$, Graves' disease $(n=4)$, and Hashimoto's thyroiditis $(n=5)$. All specimens had been fixed in $10 \%$ buffered formalin ( $\mathrm{pH} 7.0)$ and embedded in paraffin for sectioning and histological studies.

\section{Detection of MBP by immunofluorescence staining}

Indirect immunofluorescence for the detection of eosinophil granule MBP in formalin-fixed paraffin-embedded sections was performed as described previously (21). In brief, three $6-\mu \mathrm{m}$ serial sections were cut from each paraffin block and affixed to glass slides by LePage's Bond Fast resin glue (LePage's Ltd., Bramalea, Canada). The first and third sections were used for immunofluorescence, and the second section was stained with hematoxylin-eosin. For the immunofluorescence procedure, two sections from each block were deparaffinized in xylene and rehydrated in absolute alcohol, $80 \%$ ethanol, and distilled water. The sections were incubated for $1 \mathrm{~h}$ at $37 \mathrm{C}$ in a $0.1 \%$ trypsin solution to unmask antigenic sites, then incubated overnight in $10 \%$ normal goat serum to block nonspecific binding by fluorescein-labeled second antibody, goat antirabbit IgG. The slides were washed and overlaid with equal concentrations of either normal rabbit IgG (NRIgG) or affinitypurified rabbit anti-MBP. After incubation at $37 \mathrm{C}$ for $30 \mathrm{~min}$, the sections were washed and incubated for $30 \mathrm{~min}$ in $1 \%$ chromotrope $2 \mathrm{R}$ to block nonspecific binding of fluorescein dye to the eosinophils. After another wash, the sections were overlaid with affinity-purified fluoresceinated goat antirabbit IgG and incubated at $37 \mathrm{C}$ for $30 \mathrm{~min}$. After a final wash, the slides were mounted with glycerol containing paraphenylenediamine to delay the fading of fluorescence, coverslipped, and sealed with clear nail polish.

The slides were examined with a Zeiss (Carl Zeiss, Inc., Oberkochen, Germany) standard microscope equipped with standard light illumination, Zeiss IV FL vertical illumination for epifluorescence, and a fluorescein filter system. Areas showing positive immunofluorescence indicative of eosinophil infiltration and degranulation were photographed, and the corresponding areas on consecutive hematoxylin- and eosin-stained sections were documented for reference.

The specificity of anti-MBP staining in formalin-fixed paraffinembedded tissue has been investigated in detail and reported previously (20-23). Briefly, immunoabsorption of anti-MBP serum with MBP removed reactivity, whereas immunoabsorption with unrelated basic proteins failed to remove reactivity. To further reduce the possibility of nonspecific staining of other tissue elements, we used affinity chromatography-purified reagents. In the first stage of the assay, an affinity chromatography-purified rabbit antihuman MBP was used to localize $\mathrm{MBP}$, and a staphylococcal protein A-purified NRIgG was used as the negative control. The preparation of these reagents has been described in detail previously (20). Equal concentrations of NRIgG and the affinitypurified anti-MBP were used in the immunofluorescence procedure. The affinity-purified anti-MBP does not react with normal tissues, including lung (22), skin (22), lymph node (24), kidney (25), liver (26), and orbital tissue (27). In addition, we used an affinity-purified fluoresceinconjugated goat antirabbit IgG (Southern Biotechnology Associates, Birmingham, AL) as the second stage antibody.

\section{Immunohistochemistry}

Immunohistochemical staining of tissue sections was performed using monoclonal antibodies directed against thyroglobulin, CD2 (lymphocytes), CD3 ( $\mathrm{T}$ cells), CD26 (B cells), and CD45RO (memory T cells / macrophages; all obtained from Dakopatts Corp., Santa Barbara, CA) in a highly sensitive three-stage immunoperoxidase protocol, as described previously (27-29). Parallel sections with the primary antibody replaced by unrelated antibodies, nonimmune mouse $\operatorname{IgG}$ of the same isotype, and with omission of each layer in turn were examined to further assure specificity and exclude cross-reactivities between the antibodies and conjugates employed.

\section{Evaluation of immunofluorescent staining}

Tissue eosinophilia, as demonstraled by immunofluorescent staining of intracellular MBP, and eosinophil degranulation, as demonstrated by extracellular MBP deposition, were evaluated in a blinded protocol by two independent observers. The degree of eosinophil infiltration characteristic of the entire specimen was subjectively scored on a scale from 0 to $3+$ at $\times 160$ magnification. If no or only a rare eosinophil was present, a score of 0 was assigned; if tissue sections contained a few eosinophils, a score of $1+$ was assigned. A tissue section containing moderate numbers of eosinophils was scored $2+$, and a section containing numerous and confluent eosinophils was scored $3+$. The degree of extracellular MBP deposition was scored similarly. If no extracellular MBP staining was present, a score of 0 was assigned, minimal extracellular MBP deposition was scored $1+$, moderate quantities (involving between 10 $33 \%$ of the tissue) were scored $2+$, whereas $3+$ was assigned to specimens exhibiting marked deposition of MBP $(>33 \%$ of the tissue involved).

\section{Statistical analysis}

Statistical analysis was performed using $\chi^{2}$ analysis. $P<0.05$ was considered a statistically significant difference.

\section{Results}

Tissue specimens obtained from the anterior neck mass of all 16 patients with IFT revealed the typical histological features of an invasive fibrosclerotic process that extended beyond the thyroid capsule and infiltrated into the surrounding neck musculature (Fig. 1A). In addition, in all specimens examined, marked infiltration into the fibrous connective tissue and the adjacent strap muscles by mononuclear cells was present (Fig. 1B). In 11 of 16 specimens, thyroid tissue was largely replaced by collagen fibers and dense connective tissue (Fig. 1C). In fact, in 12 of 16 specimens, immunostaining for thyroglobulin revealed the presence of only small remnants of residual thyroid tissue (Fig. 1D).

Immunofluorescent localization of MBP could be categorized as one of four obvious patterns: 1 ) infiltration by intact eosinophils into connective tissue in the virtual absence of extracellular deposition of MBP (Fig. 2, A and B), 2) coexistence of tissue infiltration by intact eosinophils as well as extracellular MBP deposition (Fig. 2, C and D), 3) a punctate pattern of extracellular MBP deposition in proximity to dense collagen bundles and within dense fibrous tissue in the virtual absence of intact eosinophils (Fig. 2E), and 4) absence of intact eosinophils and presence of a diffuse staining pattern of extracellular MBP deposition within dense connective tissue and adjacent neck musculature, reflecting massive eosinophil degranulation (Fig. 2F).

Eosinophil infiltration and extracellular MBP deposition were observed in 15 of 16 patients with histologically proven Riedel's invasive fibrous thyroiditis. Infiltration of tissue specimens by intact eosinophils was graded +3 in $5,+2$ in $8,+1$ in 2 , and 0 in one instance. Extracellular MBP deposition was graded +3 in $3,+2$ in $7,+1$ in 5 , and 0 in one instance. By contrast, no extracellular deposition of MBP was detected in any of the control tissues (0 of 18) derived from 4 patients with Graves' disease, 5 patients with Hashimoto's thyroiditis, 4 patients with euthyroid multinodular goiter, and five normal individuals (each $P$ $<0.0001$ compared to IFT specimens). A few scattered eosinophils, present in most thyroid tissue samples (multinodular goiter, Graves', and Hashimoto's specimens) were similarly detected in normal thyroid tissue. Only one Graves' specimen and two Hashimoto's specimens revealed eosinophil numbers slightly greater than those in 

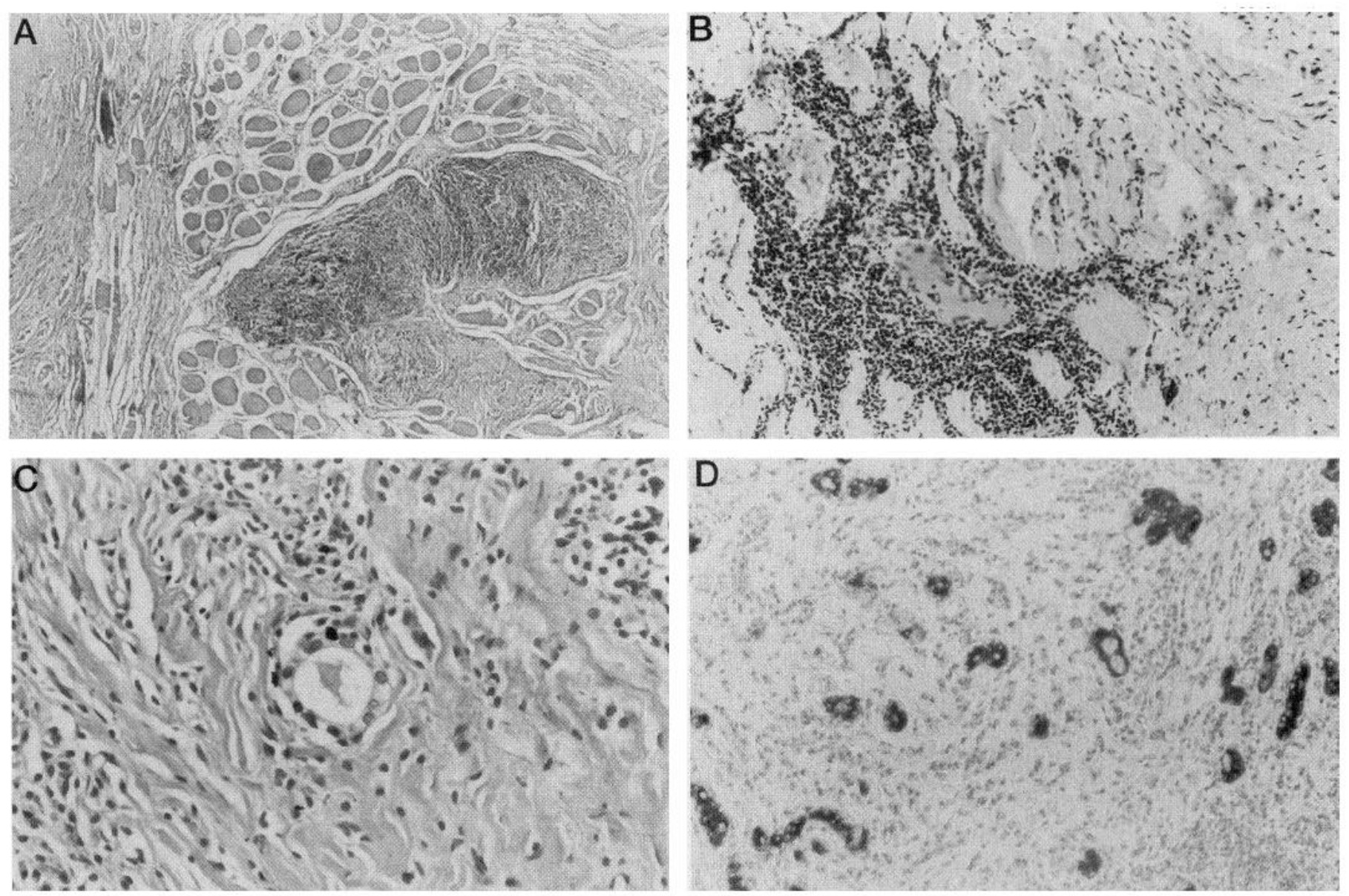

FIG. 1. Histological sections of thyroid tissue derived from a patient with IFT. Note the invasive nature of the fibrosclerotic process that extends beyond the thyroid capsule and infiltrates into the adjacent neck musculature (A; hematoxylin and eosin stain; original magnification, $\times 80$ ). A higher power view demonstrates marked infiltration of the neck musculature by lymphocytes, macrophages, and eosinophils (B; hematoxylin and eosin stain; original magnification, $\times 160$ ). C, An isolated thyroid follicle encased by collagen fibers and dense connective tissue infiltrated by mononuclear cells (hematoxylin and eosin stain; original magnification, $\times 240$ ). Immunostaining for thyroglobulin demonstrates a small number of remnant thyroid follicles and the replacement of thyroid tissue by the dense fibrosclerotic process (D; original magnification, $\times 160)$.

normal thyroid tissues. However, quantitation of eosinophil numbers in these specimens produced a score of 0 $(P<0.0001$ compared to IFT)

In all but one IFT specimen, infiltration by intact eosinophils was generally most prominent in areas of loose connective tissue and was found throughout the fibrous process (Fig. 3A). Dense fibrous tissue surrounding mononuclear cell aggregates showed both intact eosinophils and punctate extracellular MBP deposits (Fig. 3B). In addition, in both the perivascular spaces of numerous blood vessels and within mononuclear cell aggregates, intense staining for intact eosinophils as well as extracellular MBP were noted (Fig. 4, A-D). Further, in all but one IFT specimen, large numbers of intact eosinophils were detected in areas where the fibrous process was diffusely infiltrated by $\mathrm{CD}^{+} / \mathrm{CD} 45 \mathrm{RO}^{+}$-activated lymphocytes and macrophages. In apparent contrast to this pattern, intact eosinophils and MBP deposits were not detected in the central portion of aggregates populated predominantly by B lymphocytes (data not shown). Further, marked tissue eosinophilia and MBP deposition were present in areas where the fibrous process invaded adjacent structures, namely the striated neck musculature (Fig. 5, A and B). In these areas, diffuse extracellular MBP deposition was frequently observed, reflecting profound eosinophil degranulation and extensive MBP release into the surrounding tissue (Fig. 6A). In contrast to the pronounced tissue eosinophilia and MBP deposition in areas affected by the fibrogenic process, the remaining thyroid tissue in all IFT specimens was virtually devoid of both intact eosinophils and extracellular MBP deposits (Fig. 6B).

\section{Discussion}

Tissue eosinophilia and eosinophil degranulation occur in various syndromes associated with fibrosis, such as the toxic oil syndrome, the eosinophilia myalgia syndrome, the hypereosinophilic syndrome, eosinophilic endomyocardial disease, and the nodular sclerosing variant of Hodgkin's disease $(24,30,31)$. In addition, infiltration with eosinophils has been associated with a variety of immune-mediated conditions, including urticaria (20), allograft rejection $(25,26)$, and orbital pseudotumor (27). Recently, tissue eosinophilia and eosinophil degranulation were reported in the majority of patients with inflammatory fibrosing conditions, including retroper- 

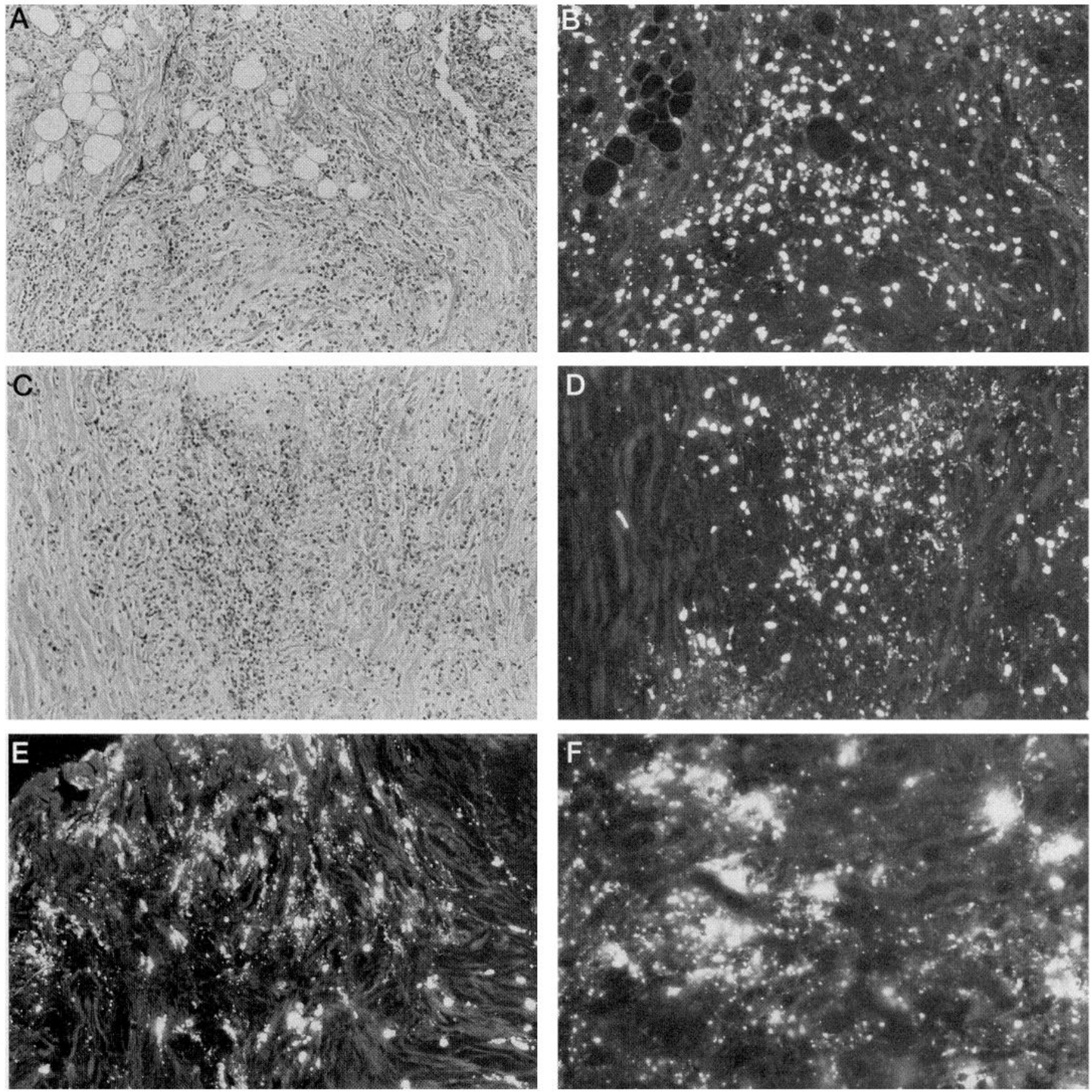

FIG. 2. Representative examples of the various patterns of tissue eosinophilia and extracellular MBP deposition observed in serial sections stained with hematoxylin and eosin (A and $\mathrm{C}$ ) or rabbit antihuman MBP antibody $(\mathrm{B}, \mathrm{D}, \mathrm{E}$, and F). A and B, Tissue infiltration by intact eosinophils; C and D, coexistence of pronounced tissue infiltration by intact eosinophils and faint extracellular MBP deposition; E, punctate pattern of extracellular MBP deposition; F, marked degree of eosinophil degranulation as demonstrated by a diffuse staining pattern of extracellular MBP deposition. The scores for eosinophil infiltration were $+3(\mathrm{~B}),+2$ ( $\mathrm{D}$ and $\mathrm{E}$ ), and +1 (F), and the scores for extracellular MBP deposition were +1 (B), +2 (D), and $+3(\mathrm{E}$ and F; original magnifications, $\times 160$; magnification for $\mathrm{F}, \times 240$ ).

itoneal fibrosis, sclerosing cholangitis, sclerosing mediastinitis, and pulmonary fibrosis (18).

In this study, we tested the hypothesis that eosinophil infiltration and eosinophil degranulation, as demonstrated by the intra- and extracellular localization of MBP, are as- sociated with IFT. Previously, this condition has not been associated with marked eosinophil infiltration as a prominent feature. We found marked infiltration by eosinophils and extracellular deposition of MBP within the fibrosclerotic process in IFT. The magnitude of eosinophil infiltration cor- 

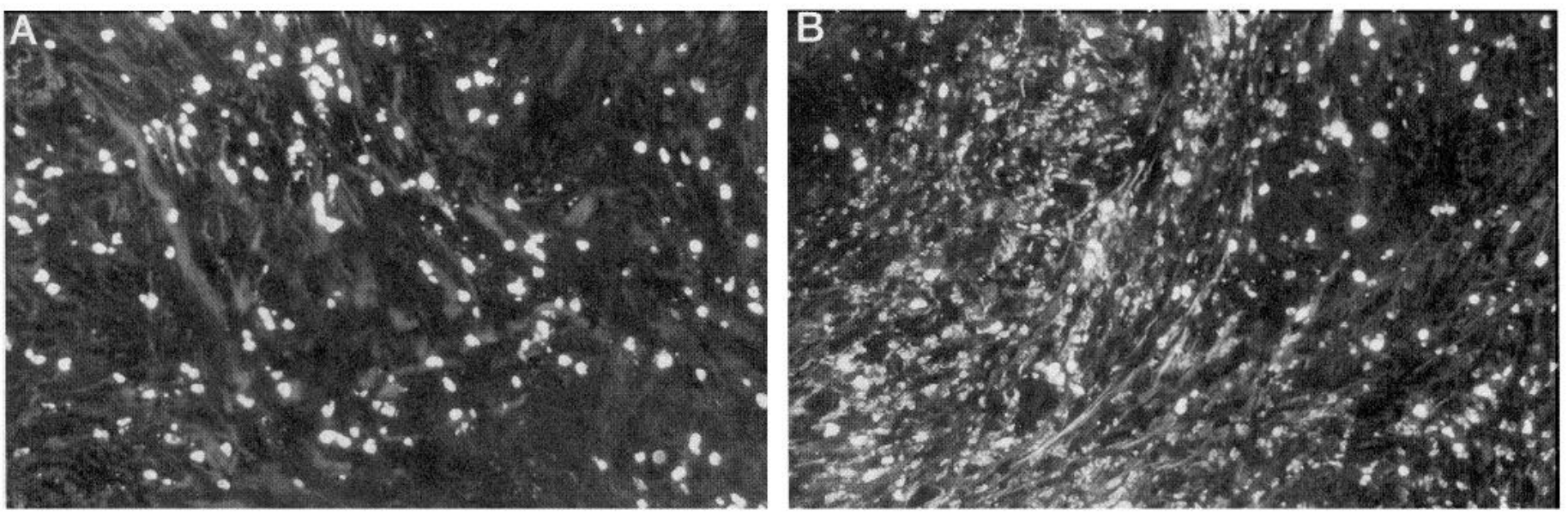

FIG. 3. Representative examples of tissue eosinophilia and extracellular MBP deposition observed in serial sections stained with rabbit antihuman MBP protein antibody. A, Infiltration of loose connective tissue by predominantly intact eosinophils. B, Strands of dense connective tissue surrounding B cell-rich lymphoid follicles and remnant thyroid follicles reveal the presence of both intact eosinophils and extracellular MBP deposits (original magnifications, $\times 160$ ). The scores for eosinophil infiltration were +2 (A and B), and the scores for extracellular MBP deposition were zero $(\mathrm{A})$ and $+2(\mathrm{~B}$; original magnifications, $\times 160)$.
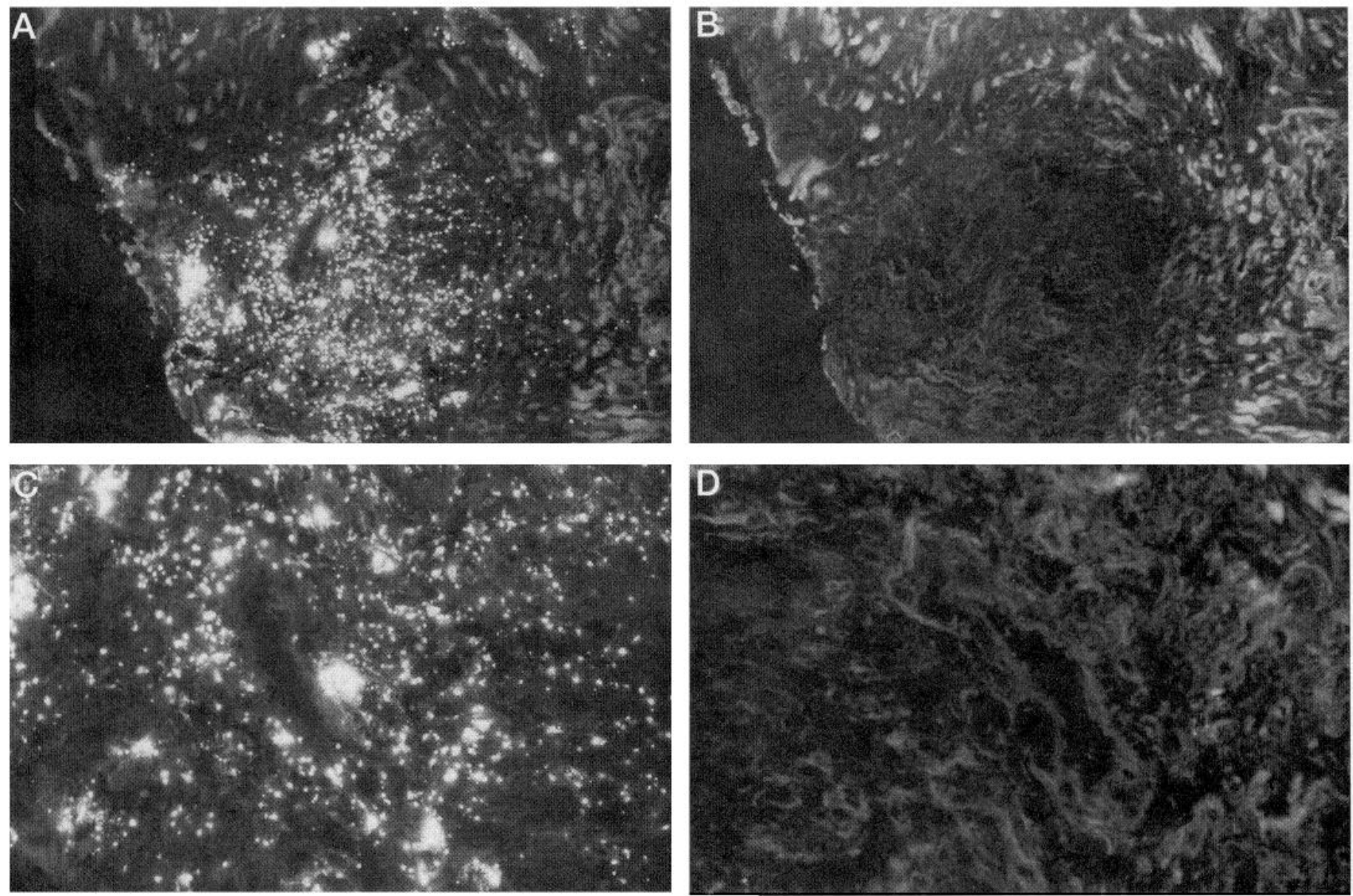

FIG. 4. Eosinophil infiltration of fibrous tissue in a biopsy specimen taken from the lateral portion of the thyroid gland in a patient with IFT. $\mathrm{A}$ and $\mathrm{C}$, Section stained with rabbit antihuman MBP antibody; B and D, serial section stained with normal rabbit IgG (original magnifications, $\times 80$ and $\times 160$, respectively). Marked infiltration by intact eosinophils (brilliantly fluorescent ovals) and extracellular MBP deposition is concentrated in the perivascular area and the adjacent connective tissue, whereas more distant areas are spared. The score for eosinophil infiltration was +1 , and the score for extracellular MBP deposition was +3 . 

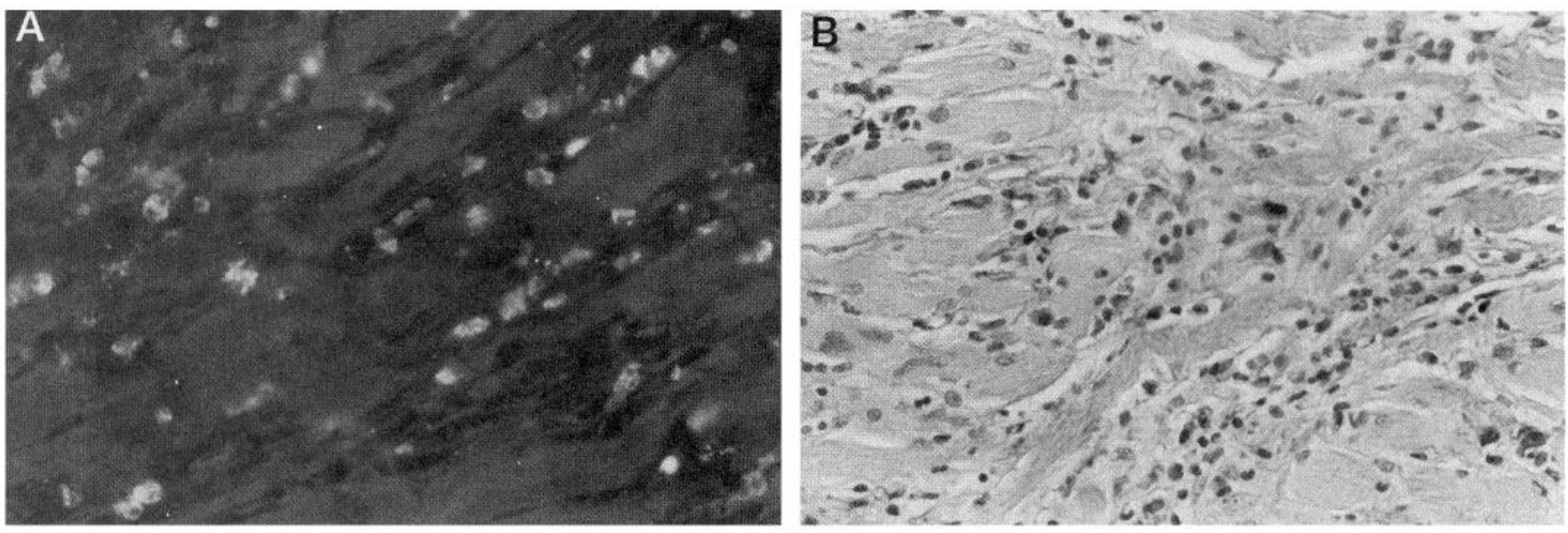

FIG. 5. Infiltration by eosinophils and deposition of MBP in a biopsy specimen taken from the lateral portion of the anterior neck mass of a patient with IFT. A, Section stained with rabbit antihuman MBP; B, serial section stained with hematoxylin-eosin. Both intact eosinophils and small extracellular MBP deposits are present in areas showing mononuclear cell infiltration and disruption of skeletal muscle (original magnifications, $\times 200$ )
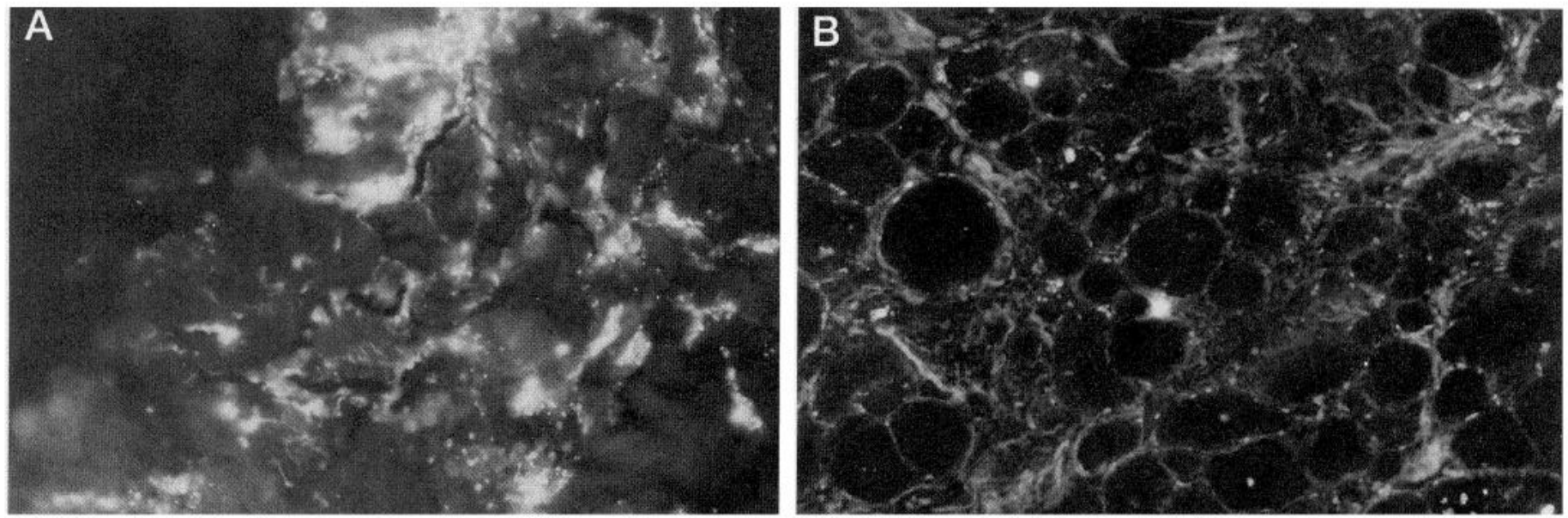

FIG. 6. A, Marked deposition of extracellular MBP in a biopsy specimen taken from the lateral portion of the anterior neck mass of a patient with IFT. Note the stringy staining pattern of extracellular MBP deposition surrounding degenerating skeletal muscle fibers. B, Normal appearing thyroid tissue located in an area not affected by invasive fibrosclerosis in a patient with IFT. Note the presence of only occasional eosinophils and the absence of extracellular MBP deposits (original magnifications, $\times 200$ ).

related best with the presence and extent of inflammatory infiltrates rich in activated $\mathrm{T}$ lymphocytes/macrophages and was most marked in perivascular zones and areas with abundant immature connective tissue. Of note, the single patient with IFT and no evidence of tissue eosinophilia or eosinophil degranulation presented clinically with a 4 -yr history of a thyroid mass, and histology revealed extensive fibrosis with only minor infiltration by inflammatory cells, suggesting long standing inactive disease.

The distribution of extracellular MBP deposits commonly paralleled that of intact eosinophils. However, these deposits were also found independent of intact eosinophils, particularly in dense connective tissue and areas of fibrous invasion into thyroid and striated muscle tissues. These results together with prior observations (18) suggest that eosinophils migrate into immature connective tissues, presumably in response to chemotactic stimuli (32), degranulate, and release their cationic toxins into the connective tissue. Although MBP was localized in this study, various other eosi- nophil products are probably also released, including the eosinophil cationic protein, eosinophil peroxidase, and eosinophil-derived neurotoxin $(12,13,18,33-35)$.

Several recent reports suggest a potential role for eosinophils and MBP in tissue fibrogenesis. Eosinophil extracts are capable of stimulating fibroblast proliferation, and eosinophil-conditioned medium has been shown to be mitogenic for fibroblasts, suggesting that an eosinophil product may directly cause fibrosis (17). In addition, eosinophil-derived neurotoxin appears to be capable of stimulating fibroblast proliferation (36). Furthermore, eosinophils have been shown to stimulate the replication of fibroblasts in vitro (19). Recently, eosinophils have been found to release certain cytokines $(37,38)$ and to express genes for various cytokines, including transforming growth factor $-\beta$, a potent stimulator of fibroblast chemotaxis, proliferation, and synthetic capacities (39). These observations in conjunction with our present data suggest that tissue eosinophilia and eosinophil degranulation may represent an important fibrogenic element in the 
evolution of IFT. However, the possibility of a secondary epiphenomenon is difficult to exclude and, therefore, must be considered.

IFT is generally considered to be a disease process that originates within the thyroid gland. The striking degree of tissue eosinophilia and eosinophil degranulation that we observed in perivascular areas, in the inflamed loose connective tissue, and in the interstitial connective tissue between striated muscle fibers, with virtual sparing of residual thyroid tissue, appears difficult to reconcile with this view. In fact, our immunustaining results raise the hypothesis that the thyroid gland and adjacent neck structures, although central features of multifocal fibrosis, are secondarily affected during the progression of a systemic fibrogenic process. This view is supported by a recent study showing similar marked tissue eosinophilia and degranulation in retroperitoneal fibrosis and various other fibrous conditions commonly associated with IFT (18). Perhaps, the inflammatory and destructive process in IFT is directed against thyroid connective tissue rather than thyroid epithelial cells and merely represents an extension of a cervical fibrosclerotic process into the thyroid gland. In fact, the perivascular localization of eosinophils and extracellular MBP could indicate an allergic process that involves blood vessels, supporting similar previous suggestions $(40,41)$. Thus, an etiological mechanism such as an allergic response against leaking oxidized low density lipoprolein, as proposed recently for idiopathic retroperitoneal fibrosis $(42,43)$, may also apply to IFT.

Although the primary reason for ensinophil infiltration and degranulation in IFT remains unclear, some potential mechanisms involved in eosinophil recruitment and access to inflamed connective tissue sites can be envisioned. Stimulated leukocytes, including eosinophils, are capable of binding to cytokine-stimulated fibroblasts and endothelial cells, and this adhesive interaction is blocked by RGD peptides as well as by monoclonal antibodies directed against certain leukocyte integrins $(19,44-49)$. Intercellular adhesion molecule-1 (ICAM-1; CD54) has been characterized as the receptor for the leukocyte integrins LFA1 and Mac-1, the predominant integrins expressed on human eosinophils $(19,44$, 45). In addition, ICAM-1 has been shown to regulate at least in part the adhesion of eosinophils to endothelium both in vitro and in vivo $(19,50)$. Further, ICAM-1 is expressed by fibroblasts and endothelial cells, and this expression is readily up-regulated by several cytokines $(44,49,51)$. Thus, it is possible that ICAM-1 and other adhesion molecules expressed by vascular endothelium, connective tissue cells, and thyroid follicular cells after local stimulation by inflammatory mediators contribute to the recruitment of eosinophils to sites involved by the inflammatory process in IFT. In support of this concept, we recently found markedly increased concentrations of the soluble ICAM-1 receptor in sera derived from patients with active IFT (52). Once recruited to a site of inflammatory fibrosclerosis such as the thyroid gland, eosinophils may act as antigen-presenting cells capable of antigen processing and $T$ cell activation (53), further supporting the link between IFT and autoimmune thyroid disease $(7,8)$.

In conclusion, the presence of eosinophil infiltration and extracellular MBP deposition in tissues affected by IFT and its absence in other autoimmune and nonautoimmune thy- roid conditions, suggests an as yet unrecognized role for eosinophils and their products in the pathogenesis of IFT. The release of eosinophil-derived products may represent an important factor in the evolution of a spectrum of conditions characterized by locally aberrant fibrosis, of which IFT may be only one manifestation.

\section{Acknowledgments}

The authors are grateful to Mrs. Jill Wagner, Department of Immunology, Mayo Clinic, for expert technical advice, and to Aidan Carney, M.D., Department of Pathology, for bringing the association of tissue eosinophilia and fibrosis in IFT to our attention.

\section{References}

1. Riedel BMKL. 1896 Die chronische, zur Bildung eisenharter Tumoren führende Entzündung der Schilddrüse. Verh Dtsch Ges Chir. 25:101-105.

2. Woolner LB, McConahey WM, Beahrs OH. 1957 Invasive fibrous thyroiditis (Riedel's struma). J Clin Endocrinol Metab. 17:201-220.

3. Hay ID. 1985 Thyroiditis: a clinical update. Mayo Clin Proc. 60:836-843.

4. DeLange WE, Freling NJM, Molenaar WM, Doorenbos H. 1989 Invasive fibrous thyroiditis (Riedel's struma): a manifestation of multifocal fibrosclerosis? A case report with review of the literature. Q J Med. 72:709-717.

5. Harach HR, Williams ED. 1983 Fibrous thyroiditis-an immunohistopathological study. Histopathology. 7:739-751.

6. Schwaegerle SM, Bauer TW, Esselstyn CB. 1988 Riedel's thyroiditis. Am J Clin Pathol. 90:715-722.

7. Heufelder AE, IIay ID. 1994 Evidence for autoimmune mechanisms in the evolution of invasive fibrous thyroiditis (Riedel's struma). Clin Invest. 72: $788-793$.

8. Heufelder AE, Hay ID. 1992 Expression of HLA-DR and heat shock protein 72 in Riedel's (invasive fibrous) thyroiditis. Clin Res. 40:49A

9. Hay ID, McConahey WM, Carney ID, Woolner LB. 1982 Invasive fibrous thyrniditis (Riedel's struma) and associated extracervical fibrosis: Bowlby's disease revisited. Ann Endocrinol (Paris). 43:29.

10. Kovacs EJ, DiPietro LA. 1994 Fibrogenic cytokines and connective tissue production. FASEB J. 8:854-861

11. Zimmermann-Belsing T, Feldt-Rasmussen U. 1994 Riedel's thyroiditis: an autoimmune or primary fibrotic disease? J Intern Med. 235:271-274.

12. Gleich GJ, Adolphson CR. 1986 The eosinophil leucocyte: structure and function. Adv Immunol. 39:177-253.

13. Gleich GJ, Frigas E, Loegering DA, Wassom DL, Steinmuller D. 1979 Cytotoxic properties of the eosinophil major basic protein. J Immunol. 123:29252927.

14. Seibold JR, Giorno RC, Claman HN. 1990 Dermal mast cell degranulation in systemic sclerosis. Arthritis Rheum. 33:1702-1709.

15. Ruoss SJ, Hartinam T, Caughey GH. 1991 Mast cell tryptase is a mitogen for cultured fibroblasts. J Clin Invest. 88:493-499.

16. Ayars GH, Altman LC, Gleich GJ, et al. 1985 Eosinophil- and eosinophil granule mediated pneumocyte injury. J Allergy Clin Immunol. 76:595-604.

17. Pincus SH, Ramesh KS, Wyler DJ. 1987 Eosinophils stimulate fibroblast DNA synthesis. Blood. 70:572-574.

18. Noguchi H, Kephart GK, Colby TV, Gleich GJ. 1992 Tissue ensinophilia and eosinophil degranulation in syndromes associated with fibrosis. Am J Pathol. 140:521-528.

19. Shock A, Rabe KF, Dent G, et al. 1991 Eosinophils adhere to and stimulate replication of lung fibroblasts 'in vitro.' Clin Exp Immunol. 86:185-190.

20. Peters MS, Schroeter AL, Kephart GM, Gleich GJ. 1983 Localization of eosinophil granule major basic protein in chronic urticaria. J Invest Dermatol. 81:39-43.

21. Filley WV, Ackerman SJ, Gleich GJ. 1981 An immunofluorescent method for specific staining of eosinophil granule major basic protein. I Immunol Methods. 47:227-238.

22. Filley WV, Holley KE, Kephart GM, Gleich GL. 1982 Identification by immunofluorescence of eosinophilic granule major basic protein in lung tissues of patients with bronchial asthma. Lancet. 2:11-16.

23. Maddox DE, Kephart GM, Coulam CB, Butterfield JH, Benirschke K, Gleich GJ. 1984 Localization of a molecule immunochemically similar to. eosinophil major basic protein in human placenta. J Exp Mcd. 160:29 41.

24. Butterfield JH, Kephart GM, Banks PM, Gleich GJ. 1986 Extracellular deposition of eosinophil granule major basic protein in lymph nodes of patients with Hodgkin's disease. Blood. 68:1250-1256

25. Ten RM, Gleich GJ, Holley KE, Perkins JD, Torres VE. 1989 Eosinophil granule major basic protein in acute renal allograft rejection. Transplantation. 47:959-963.

26. de Groen PC, Ludwig J, Kephart GM, Gleich GJ. 1989 The eosinophil in hepatic allograft rejection. Hepatology. 10:659.

27. Noguchi H, Kephart GK, Campbell RJ, et al. 1991 Tissue eosinophilia and 
eosinophil degranulation in orbital pseudotumor. Ophthalmology. 98:928932.

28. Heufelder AE, Wenzel BE, Gorman CA, Bahn RS. 1991 Detection, cellular localization and modulation of heat shock proteins in cultured fibroblasts from patients with extrathyroidal manifestations of Graves' disease. J Clin Endocrinol Mctab. 73:739 745

29. Heufelder AE, Bahn RS. 1993 Detection and localization of cytokine immu noreactivity in retroocular connective tissue in Graves' ophthalmopathy. Eur $\mathrm{J}$ Clin Invest. 23:10-17.

30. Tai TC, Ackerman SJ, Spry CJF, Dunnette S, Olsen EGJ, Gleich GJ. 1987 Deposits of eosinophil granule proteins in cardiac tissues of patients with eosinophilic endomyocardial disease. Lancet. 1:643-647.

31. Ten RM, Kephart GM, Posada M, et al. 1990 The participation of eosinophils in the toxic oil syndrome1. Clin Exp Immunol. 82:313-317.

32. Postlethwaite AE, Snyderman R, Kang AH. 1976 The chemotactic attraction of human fibroblasts to a lymphocyte-derived factor. J Exp Med. 144:11881203.

33. Leiferman KM, Fujisawa T, Gray BH, Gleich GJ. 1990 Extracellular deposition of eosinophil and neutrophil granule proteins in the IgE-mediated cutaneous late phase reaction. Lab Invest. $62: 579-589$.

34. Juhlin L, Venge P. 1991 Eosinophilic cationic protein (ECP) in skin disorders. Acta Dermatol Venereol (Stockh). 71:495-501.

35. Czech W, Krutmann J, Schöpf E, Kapp A. 1992 Serum eosinophil cationic protein $(\mathrm{ECP})$ is a sensitive measure for disease activity in atopic dermatitis. Br J Dermatol. 126:351-355.

36. Noguchi H, Hoerl BJ, Gleich GJ. 1990 Eosinophil-derived neurotoxin (EDN) stimulates fibroblast proliferation. FASEB J. 4:A1943.

37. Wong DTW, Weller PF, Galli SJ, et al. 1990 Human eosinophils express transforming growth factor $\alpha$. J Exp Med. 172:673-681.

38. Ohno I, Lea R, Finotto S, et al. 1991 Granulocyte/macrophage colonystimulating factor (GM-CSF) gene expression by eosinophils in nasal polyposis. Am J Respir Cell Mol Biol. 5:505-510.

39. Ohno I, Lea RG, Flanders KC, et al. 1992 Eosinophils in chronically inflamed human upper airway tissues express transforming growth factor $\beta 1$ gene (TGF $\beta 1$ ). J Clin Invest. 89:1662-1668.

40. Hardmeier T, Hedinger C. 1964 Die eisenharte Struma Riedel: eine primäre Gefäßerkrankung? Virchow Arch Pathol Anat Histol. 337:547-547.
41. Meyer S, Hausman R. 1976 Occlusive phlebitis in multifocal fibrosis. Am J Clin Pathol. 65:274-283.

42. Parums DV, Chadwick DR, Mitchinson MJ. 1986 The localization of immunoglobulin in chronic periaortitis. Atherosclerosis, 61:117-123.

43. Bullock N. 1988 Idiopathic retroperitoneal fibrosis. Br Med J. 297:240-241.

44. Springer TA. 1990 Adhesion receptors of the inmune system. Nature. 346: 425-434.

45. Hartnell A, Moqbel R, Walsh GM, Bradley B, Kay AB. 1990 Fcgamma and CD11/CD18 receptor expression on normal density and low density human. eosinophils. Immunology. 69:264-270.

46. Bochner BS, Luscinskas FW, Gimbrone Jr MA et al. 1991 Adhesion of human hasophils, eosinophils, and neutrophils to interleukin-1-activated human vascular endothelial cells: contribution of endothelial cell adhesion molecules. J Exp Med. 173:1553-1556.

47. Lamas AM, Mulroney CM, Schleimer RP. 1988 Studies on the adhesive interaction between purified human eosinophils and cultured vascular endothelial cells. J Immunol. 140:1500-1505.

48. Kimani G, Tonnesen MG, Henson PM. 1988 Stimulation of eosinophil adherence to human vascular endothelial cells in vitro by platelet-activating factor. I Immunol. 140:3161-3166.

49. Heufelder AE, Bahn RS. 1993 Elevated expression of selectin- and immunoglobulin superfamily-type adhesion molecules in retroocular tissues from patients with Graves' ophthalmopathy. Clin Exp Immunol. 91:381-389.

50. Kyang-Aung B, Haskard DO, Poston RN, Thornhill MH, Lee TH. 1991 Endothelial leukocyte adhesion molecule-1 and intercellular adhesion molecule-1 mediate the adhesion of eosinophils to endothelial cells in vitro and are expressed by endothelium in allergic cutaneous inflammation in vivo. J Immunol. 146:521-528.

51. Heufelder AE, Bahn RS. 1992 Modulation of intercellular adhesion molecule-1 (ICAM-1) by cytokines and Graves' IgGs in cultured Graves' retroocular fibroblasts. Eur J Clin Invest. 22:529-537.

52. Heufelder AE, Bahn RS. 1993 Soluble intercellular adhesion molecule-1 (sICAM-1) in sera of patients with Graves' ophthalmopathy and thyroid diseases. Clin Exp Immunol. 92:296-302.

53. Del Pozo V, De Andrés B, Martín E, et al. 1992 Eosinophil as antigenpresenting cell: activation of $\mathrm{T}$ cell clones and $\mathrm{T}$ cell hybridoma by eosinophils after antigen processing. Eur J Immunol. 22:1919-1925. 